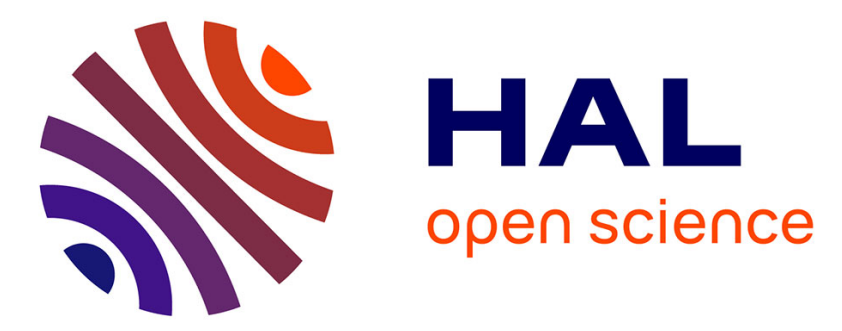

\title{
C-N-P Decoupling Processes Linked to Arable Cropping Management Systems in Relation With Intensification of Production
}

\author{
Sylvie Recous, Gwenaëlle Lashermes, Isabelle Bertrand, Michel Duru, Sylvain \\ Pellerin
}

\section{To cite this version:}

Sylvie Recous, Gwenaëlle Lashermes, Isabelle Bertrand, Michel Duru, Sylvain Pellerin. C-N-P Decoupling Processes Linked to Arable Cropping Management Systems in Relation With Intensification of Production. Agrosystem Diversity, Academic press, Elsevier, 2019, Agroecosystem Diversity Reconciling Contemporary Agriculture and Environmental Quality, 978-0-12-811050-8. 10.1016/B978-012-811050-8.00003-0 . hal-02018416

\section{HAL Id: hal-02018416 https://hal.science/hal-02018416}

Submitted on 13 Feb 2019

HAL is a multi-disciplinary open access archive for the deposit and dissemination of scientific research documents, whether they are published or not. The documents may come from teaching and research institutions in France or abroad, or from public or private research centers.
L'archive ouverte pluridisciplinaire HAL, est destinée au dépôt et à la diffusion de documents scientifiques de niveau recherche, publiés ou non, émanant des établissements d'enseignement et de recherche français ou étrangers, des laboratoires publics ou privés.

\section{(ㅇ)(1) $\$$}

Distributed under a Creative Commons Attribution - NonCommercial - NoDerivatives $\mid 4.0$ 
Authors pre-print.

In book: Agrosystem Diversity: Reconciling contemporary agriculture and environmental qualityPublisher: Edition: Lemaire, G., De Faccio Carvalho, P.C., Kronberg, S., Recous, S.Publisher: Academic Press, Elsevier, Chapter 3, pp 35-45.

\section{C-N-P decoupling processes linked to arable cropping management systems in relation with intensification of production}

Sylvie Recous ${ }^{1}$, Gwenaëlle Lashermes ${ }^{1}$, Isabelle Bertrand ${ }^{2}$, Michel Duru ${ }^{3}$, Sylvain Pellerin ${ }^{4}$

${ }^{1}$ FARE laboratory, INRA, Université Reims Champagne-Ardenne, F-51100 Reims, France

2, INRA, UMR Eco\&Sols, F-34000, Montpellier, France

3., INRA, UMR AGIR, F-, F-31326 Castanet Tolosan, France

4, INRA, UMR ISPA, F 33140 Villenave-d'Ornon, France

Abstract:

Biogeochemical cycles of carbon $(C)$, nitrogen $(N)$, phosphorus $(P)$ are naturally coupled in terrestrial ecosystems by elemental stoichiometry of plant autotrophy and of soil biological heterotrophy. The shift from natural to cropped intensive systems lead to major changes in crops land-use, nutrient availability, soil management. This chapter presents the fundamental processes of $C, N$ and $P$ coupling, and how the intensification of agriculture, has "opened" and "decoupled" the terrestrial nutrient cycles, leading to major environmental impacts, particularly with nitrogen. Intensification of agriculture has reduced the diversity of plant species and lowered organic carbon inputs to soils, increased the $N$ saturation of agrosystems by fertilization- and to a lesser extent $P$ while the territorial specialization of agriculture has increased nutrient fluxes and imbalances both at regional and world scales. These major changes have modified in turn the nature and amount of plant biomass recycled to soils, the diversity and activities of soil communities, and affected the balance of nutrient mineralization to immobilization by heterotrophs. Lack of synchrony between nutrients supply and plant demand, enhanced by the simplification of crop rotations, is also a major 
cause of decoupling between cycles. Therefore, new farming strategies should aim, at plot scale, at diversifying crops, increasing the presence of legumes in rotations and the annual soil occupancy by crops, and at increasing, at farm and regional scales, the complexity of cropping systems (particularly by mixing arable and livestock farming) so as to enhance local recycling of nutrients and decrease the use of synthetic fertilizers. 


\section{Introduction}

Increasing world population, rising environmental concerns and scarcity of resources have placed agriculture in a dual challenge: the need to maintain, and even increase, the primary productivity of cropped ecosystems to meet the increasing demand for food and non-food biomass, while limiting environmental impacts, and sustainably managing the world's critical resources for agricultural production. Over the past 50 years, the 2.5 -fold increase in world food production has been accompanied by a 8 -fold increase in the amount of nitrogen $(\mathrm{N})$ fertilizer input and an approximately 4-fold increase in the amount of phosphate fertilizer input, using mining of phosphate sedimentary rocks. However the $\mathrm{P}$ inputs have remained more or less constant since 1990, contributing to disproportionally higher N:P ratio inputs in most ecosystems (Peňuelas et al., 2012). In addition, atmospheric $\mathrm{N}$ deposition in terrestrial ecosystems is about 20 times more important than $P$ deposition, thus contributing to the $N: P$ imbalance, even in less anthropic ecosystems ( Peňuelas et al., 2012).

The atmosphere is the main source of $\mathrm{N}$, in the form of $\mathrm{N}_{2}$, since it contains $78 \%$ by volume. But atmospheric $\mathrm{N}$, however abundant, is not directly assimilated by plants because of its chemical stability which makes it a non-reactive species. The only biological transformation of molecular $\mathrm{N}$ into organic $\mathrm{N}$ is the fixation of atmospheric $\mathrm{N}$, produced by very specific microorganisms, free or in symbiosis with certain plants such as legumes. At the beginning of the 20th century (1910), the development of the Haber-Bosch process, consisting of an industrial conversion of atmospheric $\mathrm{N}$ into ammoniacal $\mathrm{N}$ and then nitric acid, led to considerable development of the $\mathrm{N}$ fertilizer industry. In contrast to $\mathrm{N}$, weathering of primary rock minerals provides the dominant source of total $P$ in natural terrestrial ecosystems (Chadwick et al., 1999). P fertilizer comes from nonrenewable phosphate sources, provided by only five countries which hold $90 \%$ of the world $\mathrm{P}$ reserves, and $P$ resource may end up becoming limiting for agricultural lands, because of the increasing demand (FAO, 2015). It is estimated that worldwide, a total of 5.7 billion hectares of land contain low levels of plant-available P (Cakmak, 2002).

Widespread use of synthetic $\mathrm{N}$ and $\mathrm{P}$ fertilizers led to an unprecedented increase in agricultural production, and use of legume crops has decreased since fertilizer was available and cheap. As a consequence, agricultural systems and regions became more specialized, and the $\mathrm{N}$ and $\mathrm{P}$ cycles became locally "decoupled" (Billen et al., 2011) leading to losses to the atmosphere or hydrosphere with dramatic impact on the environment.

The end of the 1970's was marked by a rising awareness of the environmental consequences of intensive agricultural production with growing concerns about eutrophication which was initially 
only related to $P$ inputs while controlling both $N$ and $P$ inputs to freshwaters was later deemed necessary (Conley et al., 2009). Because $\mathrm{N}$ is more mobile in soils than $\mathrm{P}$, the diffuse pollution of aquifers by agricultural nitrate (e.g., exceeding the threshold of $50 \mathrm{mg} /$ I water of nitrates $\left(\mathrm{NO}_{3}\right)$, for drinking water set by the European directive in 1980) was a strong environmental problem. Following the Rio (1992) and Kyoto (1997) summits, the role of global carbon (C) and N cycles in forecasting future climate scenarios and carbon storage potential in the continental biosphere became evident. The concept of "nitrogen cascade" (Galloway et al., 2003) which accounts for pollution transfers, emerged in the early 2000s. It is inseparable from the concept of "reactive N", which expresses that, as opposed to atmospheric diazote $\left(\mathrm{N}_{2}\right)$ which is chemically inert, all the $\mathrm{N}$ compounds involved in biological, photochemical and radiative processes present in the atmosphere and the biosphere constitute the so-called reactive $\mathrm{N}$, i.e., the reduced mineral forms of $\mathrm{N}$ (such as $\mathrm{NH}_{3}$ or $\mathrm{NH}_{4}{ }^{+}$), oxidized mineral forms ( $\mathrm{NOx}, \mathrm{N}_{2} \mathrm{O}, \mathrm{NO}_{3}{ }^{-}$) and organic compounds. Since the discovery of the Haber-Bosch process, the use of synthetic $\mathrm{N}$ fertilizers has doubled the circulation of reactive $\mathrm{N}$ on a planetary scale (Erisman et al., 2008; Sutton et al., 2011), resulting in a range of effects associated with increasing concentrations or excess in agro-ecosystems and natural, terrestrial and aquatic ecosystems (leading to eutrophication of watersheds and sea coasts) and in the atmosphere (leading to air pollution and climate change). For example, on a European scale, agricultural soils account for $54 \%$ of $\mathrm{N}_{2} \mathrm{O}$ emissions (Hertel et al., 2012), and for France $81 \%$ of total $\mathrm{N}_{2} \mathrm{O}$ emissions come from agriculture, of which $82 \%$ are from fertilized croplands and $4.5 \%$ from livestock (CITEPA 2016).

In contrast to the tendency for an increase of the N:P ratio at the global scale (Peñuelas et al., 2012), $P$ is polluting some agricultural areas with intense pasture grazing and application of animal excreta slurry for fertilization, with high inputs of $P$ from off-farm concentrates, mostly imported (e. g., soybeans), leading to a decrease of the $\mathrm{N}: \mathrm{P}$ ratio of lakes and streams. In areas with crops receiving high rates of $P$ fertilizers, $P$ tend to remain and accumulate in soils because $P$ is strongly bound in insoluble forms to soil particles which strongly decrease fertilizer $P$ efficiency. The potential is much greater for soil $\mathrm{P}$ retention than for $\mathrm{N}$ retention and there are fewer loss pathways for $P$ than for $N$. These are the reasons for significant accumulation of $P$ in many areas under intensive crop production and pasture grazing in Europe and the USA (McLauchlan, 2006). Ringeval et al. (2014) using computations at country level over the period 1945-2009, with France chosen as a typical western European country with intensive agriculture, found that, on average, $82 \%$ of soil $P$ (sum of labile and stable pools) was anthropogenic, i.e. derived from $P$ fertilizers. They showed that the contribution of anthropogenic $P$ to food production was similar, at $84 \%$, indicating the high human perturbations of the $\mathrm{P}$ cycle in agroecosystems. Moreover, $\mathrm{P}$ 
accumulation in soils may lead to significant $P$ transfers to aquatic ecosystems by soil erosion, with subsequent negative effect due to eutrophication.

Within these chains - or cascades - the mineral nutrition of the crops and the fertilization play a major role. However, the influence of agriculture on biogeochemical cycles and their environmental impacts is not limited to the direct effects of fertilization on crop production and nutrients losses, and on exports or recycling of elements contained in crops or crop residues. All the practices that affect the type of plant covers, the dates and conditions of the establishment of crops and soil management, while not deliberately targetting the control of mineral nutrition, have important repercussions on the dynamics of absorption of mineral elements by plants and on the

possible loss of these nutrients. Jarvis et al. (2011) clearly showed the impacts of farming systems as a whole, on farm $\mathrm{N}$ budgets and the consequences on $\mathrm{N}$ leakages. Moreover, the decoupling of $\mathrm{C}$ and nutrient cycles is likely to boost these leakages and losses from the system.

In this context, this chapter develops the basis of coupling $\mathrm{C}, \mathrm{N}$ and $\mathrm{P}$ cycles in cropped soils and to explaining how management practices in intensive arable systems, led to decoupling of these cycles. Most of the examples will concern N, considering the quantitative importance of this element, but many findings apply similarly to $P$ and to a lesser extent to sulphur (S).

\section{Processes involved in the coupling of $\mathbf{C}, \mathbf{N}$ and $\mathbf{P}$ cycles in soils}

The cycles of carbon, nitrogen and phosphorus are "naturally" coupled in terrestrial ecosystems by elemental stoichiometry of plant autotrophy and soil microbial heterotrophy (Soussana and Lemaire, 2014). In naturel ecosystems, the $\mathrm{N}$ requirements for plants and soil organisms, coupled with relatively low levels of available $\mathrm{N}$ in many temperate and boreal forests ecosystems, causes atmospheric $C$ uptake by plants and storage on land (soil + plants) to be tightly regulated by the $\mathrm{N}$ cycle (Vitousek and Howarth, 1991). Increases in N in ecosystems (e.g., via atmospheric deposition or symbiotic $\mathrm{N}$ fixers) is usually matched by significant increases in $\mathrm{C}$ storage, until $\mathrm{N}$ limitation of plants growth is alleviated (Asner et al., 1997), and if no other limiting factor prevails.

\section{Role of soil microorganisms and drivers}

The heterotrophic soil microorganisms, bacteria and fungi mainly, also called "microbial biomass", derive their energy and the elements necessary for their growth from the decomposition of organic matter. This results in mineralization of part of the carbon in the ultimate form of $\mathrm{CO}_{2}$ 
emitted to the atmosphere, the other part being assimilated in microbial bodies. The microorganisms are subject to death and microbial recycling or are, in turn, consumed by predator organisms. Therefore the partition between mineralization and assimilation occurs later during microbial recycling, ultimately leading to most of the $C$ being mineralized and the other part, the biomass-derivated $\mathrm{C}$, being stabilized through mineral association. Therefore, the activity of heterotrophic organisms directly affects nutrient cycles, through the proportions of these nutrients in different compartments, i.e., the added (sometimes called "fresh" or "exogenous") and humified (sometimes called "native" or "endogeneous" or "stabilized") organic matters, both substrates mineralized by the heterotrophic organisms. These proportions of elements, called stoichiometric ratios $(C: N: P: S)$ and their variations across the different compartments, their stability or possible flexibility, govern the intensity of fluxes between compartments but also reflect the strong coupling between the nutrient cycles throughout the different levels of the food webs in soils (Manzoni et al., 2012, Soussana and Lemaire, 2014). While the stoichiometry ratio can vary greatly in plants according to species, maturity, conditions of growth and nutrition (Sardans et al.., 2012), substrate origin and processing types for organic products (Kallenbach and Grandy 2011), the stoichiometry of soil organisms is considered highly constrained (Cleveland and Liptzin, 2007). Microbial processing narrows the elemental ratio during litter decomposition and the build-up of SOM (Mooshammer et al., 2014), while the structure and function of microbial communities and predominating life strategy adapt to the altered resources (Fanin and Bertrand, 2016). In a metaanalysis using 186 published observations on $\mathrm{C}, \mathrm{N}$ and $\mathrm{P}$ in the soil biomass, Cleveland and Liptzin (2007) showed that, even though a large range of nutrient concentration was observed in the microbial biomass, element ratios scaled isometrically and were constrained: $\mathrm{C}: \mathrm{N}$ ratios averaged $8.6 \pm 0.3$ and $\mathrm{N}: P$ ratios averaged $6.9 \pm 0.4$. Based on this analysis, the authors estimated that the average soil microbial biomass C:N:P ratio is 60:7:1. More recently, Xu et al. (2013) estimated over a wider range of data and biomes that the average C:N:P stoichiometry for soil microbial biomass is $42: 6: 1$.

Among several factors influencing $\mathrm{C}$ degradation and $\mathrm{N}$ or $\mathrm{P}$ mineralization-immobilization, one of the most important ones is the quality of the substrate to decompose, i.e., its biochemical and physical characteristics, which determine the intrinsic biodegradability and dynamics of decomposition. This factor received considerable attention in the past decades, due to its strong effect on nutrient dynamics in soils on the short term, and on soil organic matter dynamics on the medium to long term. There is a large diversity of plant litter according to plant species, plant maturity and plant parts, and diversity in the composition of organic wastes and manures, according to the substrate's origin and process. This makes it difficult to predict the $\mathrm{C}$ 
mineralization and nutrient release from these organic substrates recycled to soils, despite considerable amount of research on this topic (Trinsoutrot et al., 2000; Jensen et al., 2005; Justes et al., 2009; Bertrand et al., 2006; Lashermes et al., 2010).

The nature of the resource and the microbial activities affect the intensity of processes that consume or feed mineral and organic forms, i.e., mineralization (also called gross mineralization to distinguish it from net mineralization) and microbial assimilation (also called gross immobilization), which balance determines the net mineralization, i.e. the availability of mineral forms in the soils. C:N, C:P and C:S ratios of plant litters are considered as indicators of whether $\mathrm{N}, \mathrm{P}$, or $\mathrm{S}$ is mineralized or immobilized during decomposition. Net immobilization of $\mathrm{N}, \mathrm{P}$ and $\mathrm{S}$ is likely to occur if residues added to soil have a C:N ratio greater than 40 (Vigil and Kissel, 1991), C:P ratio greater than 300 (Curtin et al., 2003) and C:S ratio greater than 400, respectively (Niknahad-Gharmakher et al., 2012). Güsewell and Gessner (2009) observed that critical N:P ratios which can limit the decomposition of litter, vary according to nutrient richness, and no critical single $\mathrm{N}: \mathrm{P}$ ratio can be determined. Their results suggest that the litter $\mathrm{N}: \mathrm{P}$ ratio contributes to determining the relative importance of bacteria and fungi in the decomposition process, with low $\mathrm{N}: \mathrm{P}$ ratios promoting bacteria and high $\mathrm{N}: \mathrm{P}$ ratios promoting fungi.

In soils, the gross mineralization flux, is primarily driven by the amount, the chemical recalcitrance and the physical accessibility of the organic matter sources (particularly with humus) to enzymes degradation. The gross immobilization flux is directly linked to the microbial assimilation requirements during $\mathrm{C}$ decomposition. Therefore the two opposite fluxes, which form the mineralization-immobilization turnover, are influenced differently by agricultural practices while both of them are driven by environmental conditions (temperature, moisture) that affect microorganism growth and activities. Using isotopic $\mathrm{N}$ techniques, it has been observed that gross $\mathrm{N}$ immobilization rates were very different in soils under annual crops and grassland systems (Booth et al., 2005; Attard et al., 2016), grassland systems having much higher $\mathrm{N}$ fluxes thanks to high litter and root inputs and fast turnover of fresh organic matter and microbial biomasses, while the net $\mathrm{N}$ mineralization rates were in the same range (Hart et al., 1994). But the "classical view" of the nutrient availability to plant uptake, being the balance between gross mineralization and gross immobilization, was questioned in the early 2000. Schimel \& Bennet (2004) and others, showed that plants can compete successfully for $\mathrm{N}$ even in an $\mathrm{N}$-limited environment. Indeed plants may be poor competitors with soil microorganisms at the root segment, local scale, but due to microsite heterogeneity, be successful at the whole root system/plant scale. There are microsites where net $\mathrm{N}$ mineralization dominates and others where net $\mathrm{N}$ immobilization 
dominates. Therefore, the existence of microsite heterogeneity allows plant roots and mycorrhizae access to $\mathrm{N}$ that would otherwise be taken up by microbes. Therefore, the continuous process of mineralization of organic $\mathrm{C}$ as $\mathrm{CO}_{2}$ in soils by heterotrophic microbial activity, lead inevitably to extra mineral $\mathrm{N}$ production, released in the soil. When an organic substrate enters a soil, the $\mathrm{N}$ demand of the decomposers temporarily increases with these needs being met by two sources: the direct or indirect (after mineralization) assimilation of $\mathrm{N}$ derived from the added organic substrate and the assimilation of the available soil mineral $\mathrm{N}$. In situations of high concentration of labile $C$ from substrates in the soil, e.g. due to exudation in the close vicinity of roots, or at the interface between soil and particles of decomposing crop residues, in the detritusphere or in a mulch, the nutrients availability might be scarce compared to the microbial demand of decomposers. There are several consequences of this limitation for the soil and the plant: the substrate decomposition may be slowed down leading temporary to accumulation of organic $\mathrm{C}$ in the soil, the microbial heterotrophic community may change to adapt to nutrient limitation, i.e. degrading $\mathrm{C}$ with less $\mathrm{N}$, the competition for $\mathrm{N}$ between the soil microbes and plant roots may impact the $\mathrm{N}$ nutrition and growth of the crop. Surprisingly, these situations are often encountered in cropped soils, even in highly fertilized growing situations where systems are considered saturated with $\mathrm{N}$, because either carbon or nutrients are not available together either spatially or temporally. These principles are fundamentally similar for the $\mathrm{P}$ (and $\mathrm{S}$ ) cycling with mineralization and immobilization fluxes associated with $\mathrm{C}$ dynamics and heterotrophic microbial growth and recycling, even much less studied (Ha et al., 2008; Niknahad-Gharmarkher et al., 2012).

In conclusion, while gross mineralization is a step which potentially decouples the $\mathrm{C}$ and nutrient cycles by releasing mineral forms whose fate may be distinct, the intensity of this decoupling will depend on several physiological parameters of the microorganisms (carbon and nutrient use efficiencies, turnover), on the stoichiometric relationships of the substrates and of the organisms along the trophic chain, and on the respective intensity of the different processes; microorganisms can even assimilate organic $\mathrm{N}$, avoiding the mineral $\mathrm{N}$ release in the soil; mineralization-immobilization. fluxes can be very high (such as under grassland) without any accumulation in the mineral $\mathrm{N}$ pool; plant may have access to mineral $\mathrm{N}$ by preempting directly $\mathrm{N}$ released by ammonification in the close vicinity of their roots. 


\subsection{Role of plant traits}

There is an increasing recognition of direct and indirect effects of crops on the cycling of $\mathrm{C}$ and nutrients in soils through their impact on soil microbial communities (Jangid et al., 2008). The direct effects are linked to rhizosphere interactions with the physical and chemical characteristics of the surrounding soil, the release of exudates and the depletion of nutrients and water, the presence of symbiotic microorganisms for $\mathrm{N}$-fixing species where appropriate (see Chabbi and Rumpel, this book). Indirect effects are linked to crop development and the dynamics of nutrient accumulation during crop life, above and belowground litters' traits and their after-life effects on C and nutrients dynamics in soil after senescence or harvest (De Deyn et al., 2008; Freschet et al., 2012; Soussana and Lemaire, 2014, Prieto et al., 2015, 2016). For example, crop type directly impacts the availability of soil mineral $\mathrm{N}$ : duration of the crop growth cycle, amount and dynamics of nutrient requirements by the vegetation cover, amount and nature of the above and belowground plant litters recycled. While the question has been raised over the last 20 years, on the relationship between cultural practices, the structure of soil communities and their impact on functions (Zak et al., 2003), research on links between soil communities and soil functions have clarified this. Comparing situations with low and high $\mathrm{N}$ richness of the plant-soil system, Fontaine et al. (2011) showed that low $\mathrm{N}$ availability fosters soil communities with enzymes adapted to degradation of humified organic matter such as fungi, which will exploit soil organic matter rich in $\mathrm{N}$ (known as "mining" or destocking). In a situation of greater $\mathrm{N}$ availability and $\mathrm{C}$ source to decompose (plant litters), microorganisms assimilate available $\mathrm{N}$ during the decomposition which subsequently contributes to organic matter storage through humification. Crops having high growth rate and fast $\mathrm{N}$ uptake guide the soil-plant system towards saprophyte functioning, involving higher rates of mineralization of nutrients (De Deyn et al., 2008). Klumpp et al. (2009) showed in grasslands that slow-growing plants adapted to low disturbance have coarse roots with high tissue density, which reduces Gram(+) bacteria abundance, litter decomposition and $\mathrm{N}$ availability, while increasing soil $\mathrm{C}$ sequestration.

\section{Decoupling factors in intensive arable production}

Shifting from natural ecosystem to cultivation causes an immediate and rapid loss of soil organic carbon, reducing the SOC pools in agricultural soils to $70 \%$ of their original level on average, until reaching a new equilibrium (McLauchlan, 2006). The main mechanisms involved are the alteration of $\mathrm{C}$ inputs to soils (by removal of biomass by harvest and the recycling of more labile-type vegetation) and the increase in $\mathrm{C}$ outputs (mineralization following physical disturbance of soil). 
The conversion of native vegetation to cropping generally also results in decreases in soil $\mathrm{N}, \mathrm{P}$ and S stocks (Kopittke et al., 2017). Murty et al. (2002) showed that the conversion of forest soils to agricultural use resulted in an average loss of $15 \%$ of total $\mathrm{N}$, but less than loss of soil organic $\mathrm{C}$, indicating that the C:N ratio narrows when agriculture is introduced (McLauchlan, 2006; Butterbach-Bahl et al., 2011). The linkages between carbon and $\mathrm{N}$ cycles, determined by stoichiometry of autotrophic and heterotrophic organisms, are altered, because cropped systems typically receive excess $\mathrm{N}$ from fertilizer, and an overall decrease in OM inputs compared to native systems, prevents the $\mathrm{N}$ inputs from resulting in long-term carbon storage (Burke et al., 1989). Several management practices linked to intensive arable production had led to a partial or strong decoupling of C-N-P cycling.

Natural ecosystems (including many grasslands) exhibit a large degree of synchrony and synlocation between release and uptake potentials, biotic regulations play a greater role in maximizing nutrient recycling, losses are generally small (Soussana and Lemaire, 2014) and such systems are considered "closed". In contrasts, most arable cropping systems are generally "open", primarily because annual crops with a large $\mathrm{N}$ demand during vegetative growth are used (Jarvis et al., 2011) and such open systems are characterized by high external $N$ inputs and outputs (harvest), but also period with large $\mathrm{C}$ supply and periods of $\mathrm{C}$ starvation. Management also introduce physical disturbance of the soil structure through tillage, and affects hydrology through drainage and irrigation. These systems are considered leaky and open farming systems (Jarvis et al., 2011; Pearson, 2007). The processes involved are developed thereafter.

\subsection{Farm and agricultural area specialization}

Analysis of agriculture evolution during the $20^{\text {th }}$ century, showed both at global and at local (country) levels that the result of agriculture intensification was high specialization in many regions. This was particularly emphasized by analysis of trade fluxes of proteins at the global scale (Billen et al., 2014) showing international specialization of agriculture, where a small number of countries supply the feed requirements of many deficit countries. It has been shown that the international disconnection of food production and consumption leads to a loss of efficiency in the use of $\mathrm{N}$ (Billen et al., 2014). Le Noe et al. (2016) showed for French agriculture, that $\mathrm{N}$ surplus defined as the balance between total inputs and total outputs at the time scale of a crop cycle - which is a robust indicator of $\mathrm{N}$ losses - ranged from 16 to $176 \mathrm{~kg} \mathrm{~N} / \mathrm{ha}$ /year across the 33 French agricultural regions. The highest $\mathrm{N}$ surplus were found in regions with high livestock density which received both high inputs of animal manures and synthetic fertilizers, while regions with high $\mathrm{N}$ synthetic 
inputs only and high crop production (mostly annual crops) had low N surplus, indicative of good $\mathrm{N}$ use efficiency. $\mathrm{P}$ budget ranged from -6.4 to $41 \mathrm{~kg} \mathrm{P} / \mathrm{ha} / \mathrm{year}$, showing also large disparities between regions. The negative balance resulted from very intensive crop production with inputs of $P$ fertilizers lower than the requirements of crop growth (this was made possible without severe crop growth limitation owing to the legacy of accumulated stocks of $P$ from past excessive $P$ fertilization). Senthilkumar et al. (2012) also showed the impact of production systems on P flows (through feed, fodder and animal excretion), and particularly influenced by the livestock density. As for N, P surplus was due to partial substitution between animal manure and mineral fertilizer. Specialized agricultural systems (either cropping or livestock farming systems) are associated with the highest environmental losses (surplus) and resource consumption per unit of agricultural surface (Le Noë et al., 2017). Therefore the decoupling arises mostly from disconnection of crop and livestock farming, with nutrients extracted from croplands and exported far away for livestock feeding does not return to the croplands as manure and are replaced by synthetic fertilizers, while the crop residues cannot be used by livestock. For example, in Europe, most feed comes from oilcake - rich in $\mathrm{N}$ - imported from Argentina or Brazil (soybeans) and more recently from rapeseed (byproduct of oil used for biofuel) and produced in arable farming systems. With organic farming, Nowak et al. (2015) showed that (i) the local supply (defined as the ratio of the amount of nutrients from exchanges among farms plus the amount of $\mathrm{N}$ from atmospheric sources, to the sum of inputs to organic farms); and (ii) the cycling index (defined as the fraction of nutrients flowing at least twice through the same farms), were greater in the mixed districts (association of crops and livestock) than in specialized districts. As concluded by Le Noë et al. (2017), the opening of the $N$ or $\mathrm{P}$ cycle associated with agricultural activity is not only a matter of agricultural practices, it is also the consequence of a highly specialized agri-food system very focused on long-distance trade, without seeking functional complementarities between close regions.

\subsection{Simplified crop rotations and reduction of crop diversity}

The first immediate effect of arable cropping is the change in land-use with a switch from natural vegetation to managed crops and a gradual change associated with "agricultural intensification". The consequence of intensification is the specialization in the production process, which leads to the reduction of the number of different plant species on a given piece of land. Historically the initial objective of such specialization was the improved efficiency due to the reduction of plant competition Therefore, monoculture has been perceived as economically more efficient, easiest to manage and harvest with the assumption that a greater efficiency can be 
achieved by growing a single species with crop-specific methods of management. System biodiversity of such agricultural systems was split into two categories according to Vandermeer et al. (1998): the planned biodiversity driven deliberately by farmers, and the associated (unplanned) diversity, which is the consequence of the former, such as diversity of above-ground and belowground recycled plant litter, soil communities, weeds, etc. This associated diversity represents an actual component of the biodiversity but is more difficult to identify and quantify. In agricultural systems, the non-harvested plant parts serve important ecological as discussed earlier. For example, their characteristics directly impact the amount and quality of organic inputs to the soil, the microbial diversity and activity, and the subsequent dynamics of nutrient mineral and organic forms (Jangid et al., 2008; Trivedi et al., 2016). Non-harvested components are also key elements of habitats and resources for soil biota and determine biophysical parameters such as soil cover and soil physical properties (aggregation, compaction, water infiltration and transport), which affect in turn erosion, water balance and nutrient retention. For example, Ferchaud et al. (2016) compared changes in soil $\mathrm{C}$ stocks after 5 to 6 years under perennial, semi-perennial and annual bioenergy crops in the same pedoclimatic conditions, and observed a much higher amount of crop residues left in soil and at the surface of the soil, at time of SOC measurements, with perennial crops (miscanthus and switchgrass) compared to other crop species, and different vertical stratification in the soil. However the only significant change in soil organic $\mathrm{C}$ stocks was obtained with semi-perennial crops treatment (fescue and alfalfa), with a significant effect of the type of rotation, but not of $\mathrm{N}$ fertilization. This example shows the important impacts of crops diversity and agricultural practices on non-harvested components of the system, and the potential consequences on soil biology and nutrients cycling. At the spatial scales on which the plant community functions, differences in the phenology of plant species, ground cover by vegetation, roots channels, litter layers, soil organic pool size and distribution, all have contributory effects to carbon, nutrients and water fluxes in soils (Swift and Anderson, 1994, Østergård et al., 2009). However, it always remains difficult to disentangle the specific effects of plants diversity from those of agricultural management applied to various crops that can mask the influence of reduction of plant diversity.

\subsection{Mineral and organic fertilization}


Until the middle of the twentieth century, the main $\mathrm{N}$ input to European farms was via fixation by legumes and subsequent recycling by animal manure spread on arable fields. Then the importance of manure- $\mathrm{N}$ in farms continuously decreased during a 30-40 year period, because of availability of cheap mineral fertilizer- $\mathrm{N}$ and the increasing demand for $\mathrm{N}$ created by increasing potential yields (Billen et al., 2011). For decades, nutrient management emphasized improving the delivery of fertilizer to the plant roots through fertilization practices and the increase in fertilizer use efficiency as reflected by metrics that describe the fate of fertilizer- $\mathrm{N}$ and $\mathrm{P}$ in the current growing season (Machet et al., 1987; Cassman et al., 2002; Drinkwater and Snapp, 2007). The low average recovery efficiency of the added mineral nutrients by crops, about $30-50 \%$ of the added fertilizer for N (Tilman et al. 2002; Jarvis et al. 2011) and even less for P (Vance, 2001), but strongly dependent on the timing of application, is a consequence of i) temporal asynchrony and ii) spatial separation between applied nutrients and crop demand (Drinkwater and Snapp, 2007) and iii) mostly for $P$, fixation on the soil matrix.

The consequences of such increase in the use for mineral fertilizers was that agricultural systems were placed in a state of "nutrient saturation" and inherently leaky because surplus additions of $\mathrm{N}$ and $\mathrm{P}$ are created at certain periods of the growth cycle to cope with climatic hazards while meeting yield objectives. For example, a decision-support tool for fertilization based on the balance-sheet method and largely used in France, aims at calculating a priori optimal conditions for crop nutrition while minimizing residual $\mathrm{N}$ at harvest (Meynard et al., 1997; Machet et al., 2017). Even in areas having high availability of animal manures, farmers still applied mineral fertilizers to overcome uncertainty in the use efficiency of organic-added $\mathrm{N}$, which creates high $\mathrm{N}$ surplus (Ministère de la transition écologique et solidaire, 2015).

The reliance on mineral fertilizer (combined with chemical control of weeds) has led to a series of consequences on agroecosystems management (i) simplified rotations became possible because mineral fertilization made it unnecessary to grow cover crops and forages (including legumes) in sequence that alternated with cash crops); (ii) removal of winter annuals have increased the presence of bare fallows: reduction of the time frame of living plant cover and Cfixation, decrease OM inputs and SOM stocks (Drinkwater and Snapp, 2007). Crop rotation affect $\mathrm{C}$ dynamics and coupling/decoupling in several ways. First, the rotation defines the sequence of crops with various $\mathrm{N}$ demands and with various amounts of $\mathrm{N}$ in residues returned to the soil. Second, the crop sequence defines the time of break between the different crops, time of tillage (or no-till) operations and possibilities (and needs) for growing cover crops (Justes et al., 1999). Third, the crop sequence affect crop growth by modifying soil properties and preventing weeds 
and diseases. For example, in such simplified rotations of western Europe, where bare fallows can be maintained from few weeks up to 9 months depending on the rotation (the duration of fallow is higher with spring crops), the risk of nitrate losses is high particularly during winter. The shape of relationship between $\mathrm{N}$ fertilizer application rate and nitrate leaching is often described as a "broken stick": relatively small changes in $\mathrm{N}$ leaching for rate of $\mathrm{N}$ applications up to the economic optimum rate, followed by large $\mathrm{N}$ losses thereafter. This is due to the fact that residual mineral $\mathrm{N}$ at harvest time changes only slightly with fertilizer applications below the crop's optimum application, but increases dramatically when a crop is over-fertilized (Shepherd and Chambers 2007; Justes et al., 1999). Similar trends were observed for $\mathrm{N}_{2} \mathrm{O}$ emissions (van Groenigen et al., 2010; Shcherbak et al., 2014). The risk of nitrate loss during fallow periods is also due to active soil organic matter, manure or cover crop residue mineralization during wet and warm period (i.e., autumn in much of northern hemisphere) combined with the lack of significant crop $\mathrm{N}$ uptake. For example, agricultural statistics in France over the agricultural season 2010-2011 (Agreste, 2014) indicated that the areas remaining totally bare during the winter accounted for $20 \%$ of the French area for field crops, while $63 \%$ of the soils were planted in winter crops and $17 \%$ were covered by cover crops to trap nitrate pending spring crop sowing. The percentage of bare soils in winter was particularly important for corn grain and sunflower crops where it accounts for two thirds of the national area.

During periods of bare soils or low plant demand, microbial assimilation is the only major route for biologically-mediated retention of residual added fertilizer $\mathrm{N}$ and mineralized soil $\mathrm{N}$. The reduction of plant-driven sinks in space and time, in such a rotation-simplified system, combined with the great irregularity in $\mathrm{C}$ supply to soil, which does not allow for sufficient immobilization of $\mathrm{N}$ by soil microorganisms, creates agricultural systems which maximize nutrient losses. This is proposed as one of the major reasons why conventional agricultural systems are leakier in nutrients than more diverse ecosystems or alternative agrosystems where the permanent cover of soils by living plants is fostered (e.g., conservation agriculture). The concept of ecosystem-scale $\mathrm{N}$ saturation, expanded to agricultural systems by Drinkwater and Snapp (2007), expresses the fact that the availability of $N$ (and $P$ ) exceeds the capacity of the ecosystem to cycle or store the nutrients in internal reservoirs that can be accessed by plants and microorganisms.

\section{Directs effects of fertilization on soil $N$ biological processes}

The frequent inputs of $\mathrm{N}$, either as mineral $\mathrm{N}$ fertilizer or animal manure, have direct impacts on soil functioning, particularly on the mineralization-immobilization turnover described earlier 
(which includes nitrification) and which determines the rates of transformation between the different reactive forms of $\mathrm{N}$. One important issue is the nitrification process, which determines in soil the rate at which any ammonium ion can be oxidized into nitrate, which has many consequences in terms of fate of added N. Nitrification rates have been shown to be higher in soils with a history of high levels of $\mathrm{N}$-fertilizer application due to the frequent stimulation of ammoniumoxidizing bacteria by their substrate, than in soils receiving low levels of $\mathrm{N}$-fertilizer application (Watson and Mills, 1998). Booth et al. (2005) in their meta-analysis of agricultural factors affecting gross $\mathrm{N}$ processes, showed that soil $\mathrm{C}$ losses (due to agricultural practices, changes in vegetation or climatic factors), may increase the ability of nitrifiers to compete with heterotrophic microorganisms for ammonium, which, in consequence, lead to higher $\mathrm{N}$ losses due to leaching. Lu et al. (2011) showed also through a meta-analysis, the effect of anthropogenic $\mathrm{N}$ addition on the terrestrial $\mathrm{N}$ cycle. Their study showed that $\mathrm{N}$ addition to soils increased the fluxes of $\mathrm{N}$ mineralization by $25 \%$, nitrification by $154 \%$ and denitrification by $84 \%$ compared to non-enriched $\mathrm{N}$ situations, $\mathrm{NH}_{4}{ }^{+}$concentration being one of the most important factor determining nitrification rate (Robertson, 1989), while immobilization remained unchanged. Thus a key role in potential $\mathrm{N}$ retention and loss from terrestrial ecosystem has been attributed to the balance of inorganic $\mathrm{N}$ immobilization by microbes and autotrophic nitrification (Tietema and Wessel, 1992; Stockdale et al., 2002).

These changes, i.e. decreases in plant $C$ inputs and SOC concentrations combined with frequent $\mathrm{N}$ saturation, have a direct impact on the structure and functioning of the soil community and typically result in a substantial reduction of soil microbial biomass. Kallenbach and Grandy (2011) did a meta-analysis, comparing microbial biomass data where systems with organic wastes (animal manures, composts, etc.) were compared to the same system with inorganic fertilizer, in a large range of agrosystems, soil types and climate (in total 297 comparisons). On average $C$ in the microbial biomass increased by $+36 \%$ and microbial $\mathrm{N}$ by $27 \%$ compared to systems without organic amendment, but the ratio of microbial $\mathrm{C}$ to microbial $\mathrm{N}$ was fairly constant in all circumstances (between 6 and 11), despite a wide variation in the manure and plant amendment $\mathrm{C}: \mathrm{N}$ ratio across studies. The authors confirmed the findings that in agricultural soils, the microbial biomass is $\mathrm{C}$-limited in most circumstances (and not $\mathrm{N}$ limited), and the addition of organic amendments may alleviate such limitation. They also confirmed a strong homeostatic relationship between microbial $\mathrm{C}$ and $\mathrm{N}$, that persist even under conditions of intensive resource additions and irrespective of the elemental stoichiometry of those resources (Cleveland and Liptzin, 2007). 


\subsection{Effects of irrigation}

Irrigated agricultural land accounts for $16 \%$ of the world's total agricultural land and $40 \%$ of agricultural production (FAOSTAT). Irrigation is developed in arid and semi-arid regions. In these regions, irrigation is a major contributor to the diffuse contamination of waters by nitrate due to excessive application of water and lack of matching between irrigation supply and crop needs, inducing water loss and nutrient leaching below the rooting zone. Mechanisms are well known, and the excess water supply reduces $\mathrm{N}$ recovery by crops, which in turn leads to higher fertilizer doses, defined as a vicious circle (Quemada et al. 2013). Generally, on irrigated crops, the fertilizer recovery efficiency is weaker than on the same non-irrigated land. Therefore, specific practices are required in irrigated areas to increase the efficiency of water and nitrogen supplied. This is a major challenge for ensuring food production (Tilman et al., 2002). The meta-analysis performed by Quemada et al. (2013) showed that for irrigated land, improved water management was the most effective strategy to reduce nitrate leaching, and did not equate to a decrease in yield and nitrogen efficiency, while a deficit in water (by decreasing irrigation) decreased both yield and $\mathrm{N}$ recovery. With a deficit of irrigation, residual $\mathrm{N}$ in soil may increase, enhancing the risk of nitrate leaching during the non-growing season. Therefore, irrigation contributes to leaky nutrient cycles when the availability of water and nutrients do not match simultaneously the crop requirements.

\subsection{Effects of soil tillage}

Tillage is one of the practices that distinguish highly intensified agricultural systems from less intensive and natural systems. There are many combinations of soil tillage techniques (for seedbed preparation, weed control, residue management, erosion management) and usually they are selected according to the local pedo-climatic, technical and socio-economic constraints (Guérif et al., 2001). Regarding the coupling-decoupling of biogeochemical cycles, does the tillage which modifies $\mathrm{C}$ storage in the soils and its stratification, impact in turn the fate of $\mathrm{N}$ and $\mathrm{P}$ in cropping systems? Do the changes in the soil communities and their activities modify significantly the nutrients fluxes and fate in agrosystems? Indeed, most of our knowledge to answer these questions, come from reverse situations, i.e. situations with reduction or abandonment of soil plowing, or through the comparison of agricultural (tilled) and grassland (no-till) systems. Agriculture with reduced or no-till systems developed greatly in the past two decades at places where the common model was full inversion tillage, first to reduce soil erosion and loss of soil fertility, then to increase soil biological quality. 
Tillage has a direct effect on soil structure by fragmentation, the initial placement of crop residues in the soil, the amount and spatial distribution of soil organic matter and nutrients, seeds of weeds and certain pathogens. Tillage also has many indirect effects via environmental characteristics (temperature, humidity, and aeration), plant rooting, physicochemical properties and water availability. These factors influence in turn the composition and activity of living communities (Holland and Coleman, 1987). Among the different tillage techniques, deep plowing is the technique whose impact is probably the most important, due to the volume of soil concerned and the inversion of the horizons that it entails (Guérif et al., 2001). Following the cessation of plowing, the formation of a vertical gradient of organic matter content is observed ( $C$ and nutrient, especially for non-mobile nutrient like $\mathrm{P}$ ) with a greater concentration of these nutrients in the surface horizon (usually the few top centimeters), whereas the total nutrient content of the soil is not always modified depending of the type of soil and the cropping systems (Constantin et al., 2010, Dimassi et al., 2013). The distribution of organic matter in the soil profile has an impact on a range of properties and processes in soil, particularly on the mineralization of humus. Reduced tillage, increased formation of macroaggregates, which in turn influences the concentration and turnover of new soil organic matter, by limiting the accessibility of $C$ substrates to microbes and fauna (Angers et al., 1997; Trivedi et al., 2015). Aggregation is providing physical protection to organic matter (Balesdent et al., 2000), therefore decreasing the rate of $\mathrm{N}$ mineralization. However lower mineralization of organic matter could be due also to colder and drier conditions in the soil surface layer of no-tilled situations (Balesdent et al. 2000). While the effects of soil tillage on composition and abundance of decomposers has been extensively documented (e.g., Mbuthia et al., 2015), the consequences on nutrient dynamics is not very clear, sometimes nil or negligible, probably because a change in tillage practice in cropping system usually does not occur alone, and is accompanied by several other major changes, including the characteristics of rotation and the use of pesticides (Mary et al., 2014). In several long-term experiments dedicated to the comparison of direct sowing and conventional deep plowing, Oorts et al. (2007) observed no significant difference on the net $\mathrm{N}$ mineralization of soil, with two sites differentiated for 33 years and 12 years, respectively. To distinguish the direct effect of soil tillage on accumulation of soil organic matter and subsequent $\mathrm{N}$ mineralization, from the indirect effect of tillage on soil temperature and moisture, the authors expressed $\mathrm{N}$ mineralization as the product of (i) the potential rate of net $\mathrm{N}$ mineralization $(\mathrm{Vp})$, at a given reference temperature and moisture), which is considered to be specific to microbial populations, to the accessibility of organic matter and the stock of organic matter; and, (ii) the time expressed as the number of days at reference temperature and moisture $(\mathrm{JN})$, which relates to the effect of temperature and moisture regimes 
on microbial activities. In the situations explored, there was no significant difference in rate of mineralization between no-till and ploughed plots. However there were differences on the number of normalized days, indicating an effect of tillage on physical conditions of the mineralizing soil layer. The number of normalized days was higher in tilled plots in early spring indicating more favorable conditions of mineralization, while the reverse situation was observed in early summer. This means that there is "seasonality" for the influence of tillage on mineralization conditions, but that, overall, the differences observed are small. Giacomini et al. (2010) looking at the fate of fertilizer- $\mathrm{N}$ in rotations of pea-wheat and maize-wheat sequences, observed little or no influence of tillage practice (reduced tillage vs. deep ploughing) on the recovery of ${ }^{15} \mathrm{~N}$-labelled fertilizer- $\mathrm{N}$ in the wheat crops nor in the fraction of fertilizer-N immobilized into the soil.

Another direct effect of introducing tillage, is the management of crop residues and organic products that lead to the incorporation of these organic sources into soil by tillage (either partially or fully). The initial location of crop residues, e.g., the presence or absence of mulch at the soil surface, the clustering of crop residues, and the spreading of fragments in the soil, modify many soil physical parameters, which in turn have a range of effects on decomposition and microbial properties. In no-till or reduced-till systems plant litters/crop residues are left at the soil surface. In such situations, soil-residue contact is limited, which make spatially distant nutrients (mainly in the soil) and added carbon (at the soil surface): crop residues having low nutrient concentration (high $\mathrm{C}: \mathrm{N}, \mathrm{C}: \mathrm{P}$ ) tend to decompose more slowly than when incorporated into the soil which is the case for example for straw of cereals harvested at maturity. The presence of a decomposing organic layer at the soil surface also translates into a higher net $\mathrm{N}$ mineralization of the underneath soil layer, due to the absence of the residue $\mathrm{C}$ incorporation and therefore lower microbial $\mathrm{N}$ immobilization due to decomposition (Coppens et al., 2006). More important is the modification of soil water and thermal regimes in the presence of residue mulch at the soil surface, which improves water penetration into the soil, and decreases water evaporation (Quemada et al., 2013). However, these effects are different according to local climatic conditions (Guérif et al., 2001).

Thus the effect of tillage as a practice considered individually is mainly connected to the physical functioning of the soil which it infers: soil structure, moistening-desiccation regime, water retention and transport and spatial distribution of plant derived-C substrate. In climatic situations favorable to decomposition, incorporation of crop residues and disturbance of roots system by ploughing accelerates their decomposition and the subsequent net mineralization of nutrients. It also accelerates the mineralization of native organic matter, by the annual mechanical disturbance of soil. Attard et al. (2016) studied the effects of reciprocal shifts from rotation of annual crops to 
temporary grassland and vice-versa; which is a common feature of ley-arable cropping systems. They observed that ploughing of the grasslands plots immediately caused an increase in the $\mathrm{CO}_{2}$ $\mathrm{C}$ emitted, and in mineralization of $\mathrm{N}$, followed by a general decrease in $\mathrm{C}$ and $\mathrm{N}$ fluxes, due to destruction of the grass, mechanical disturbance of the no-till soil and on the longer term to the cessation of high organic matter inputs from grassland. Conversely the cessation of tillage following the establishment of grass did not modify significantly soil $\mathrm{C}$ and $\mathrm{N}$ pools and mineralization fluxes during the first 3 years after the shifts, time needed for the grass to establish its perennial root system and accumulate extra $C$ into the soil. This work and others, clearly showed the asymmetric responses of cropping systems to reciprocal shifts in land use, and the strong disturbance which represents soil tillage. The reduction or suppression of tillage have been advocated to be responsible for increased $\mathrm{N}_{2} \mathrm{O}$ emissions (due to the combination of high concentrations in $\mathrm{C}, \mathrm{N}$ and moisture, in the soil top layer), and in some circumstances in higher risk of nutrients leaching due to high water retention in the soil profile. However, the reduction or suppression of tillage proved to foster many other important physical and biological characteristics, which, combined with higher and more diverse plant litter inputs, may improve soil fertility and, on the longer term, decrease the needs for fertilizers. The reduction of the biological activity in soil by tillage has been acknowledged for decades (e.g., Dick 1992), due to reduction of macro aggregation, but there is no clear evidence of significant impact on mineralization and nutrient dynamics. Therefore the effects of soil tillage or absence of tillage are complex because of the many physical and biological interactions in soil. Tillage leads to incorporation of plant residues, which foster microbial activity; the presence/absence of a residue layer at the soil surface strongly modifies temperature and moisture regimes, which may be favorable or unfavorable to microbial activities. Lastly some nitrate losses might be enhanced or reduced, via nitrate leaching or $\mathrm{N}_{2}$ and $\mathrm{N}_{2} \mathrm{O}$ emitted.

\section{Conclusions}

The intensification of agriculture in cropped systems has led to an opening of the nutrients cycles and an increase in nutrient saturation of systems, which both contributed to a partial or significant decoupling with the carbon cycle. This was first promoted by the introduction of intensive $\mathrm{N}$ and $\mathrm{P}$ mineral fertilization, which led to the decoupling of nutrients supply and demand, (i) in time: which deeply altered the succession of crops, reduced the occupancy of soils by growing plants and made marginal the contribution of $\mathrm{N}$ fixation and organic matter mineralization to nutrients supply; (ii) in space: fertilization made possible specialized farming systems on a 
regional scale, and agriculture on a world scale, increasing global nutrient flows and associated losses. Mineral fertilization, reduced crop diversity and soil disturbance by tillage have also changed the soil physical properties, the soil communities and the functions they perform. Thus, the potential for coupling of biogeochemical cycles through the degradation of organic matter (mineralization and immobilization) have been altered in intensive cropped systems, but also they became saturated by excess nutrients.

The necessary evolution of cropping systems towards greater energy and nutrient autonomy, to reduce chemical inputs, to save resources and to reduce environmental impacts, must therefore find solutions inspired from less anthropized ecosystems. Hufnagl-Eichiner et al. (2011) distinguished the measures improving the efficiency of mineral and organic inputs, from measures involving the re-design of cropping systems. Improved fertilization practices, which aims at increasing the recovery and efficiency of the applied $\mathrm{N}$, contribute to the efficiency of the systems (eco-efficient options) but do not mobilize coupling of $C$ and nutrient cycles. The optimization of agricultural practices is certainly essential to improve the closure of biogeochemical cycles and limit the nuisances towards the environment. Nevertheless, the coupling of $\mathrm{C}$ and nutrient cycles must lead to an intensification of work towards the re-design of efficient cropping systems based on knowledge and valorization of biological interactions in soils and the diversification of plant species (Duru et al., 2015). The increase in legume crops in cropping systems (Siddique et al. 2012) allows the removal of synthetic mineral fertilizers on certain phases of rotation. Practices of soil cover during intercropping periods are also means of enhancing permanent interactions between crops and soils communities, and synchrony of $\mathrm{N}$ uptake and supply, thereby reducing $\mathrm{N}$ leaching losses reducing nutrients leakage. The introduction of perennials and semi-perennials in agrosystems, and development of agroforestry systems mixing spatially trees and annual crops, also appear as promising agrosystems that enhance in time and space the biotic and abiotic interactions. Permanent cover of soils by living and dead plant biomasses combined with reduced soil tillage, constitute the foundation of conservation agriculture (Scopel et al., 2013).

A re-diversification of crops at scale of fields and cropping systems at the scales of landscapes, also appears as a major lever to increasing the sustainability of agricultural production systems, by reducing inputs (water, pesticides, and nitrogen fertilizer), increasing the heterogeneity of habitat mosaics, or reducing yield losses due to too frequent returns of the same species. Increasingly research suggests that the level of internal regulation of function in 
agroecosystems is largely dependent on the level of plant and animal biodiversity present (Kremen and Miles, 2012; Dwidedi et al., 2017).

It is important to stress that the future cannot be limited to redo what has been undone before. The new insights reported here on processes, particularly knowledge on the processes of coupling and the role of soil microorganisms, the importance of the interactions between soil physical, chemical and biological functioning allow us to go beyond reproducing the past. Also new techniques such as precision farming technologies and models are able to help both limiting leakages and designing the "right" assemblages of plants over time, and the necessary exchanges of nutrients and biomasses flows at different spatial scales. The options considered in different types of agriculture and under different soil and climate conditions are discussed in other chapters of this book. 


\section{References}

Agreste, 2014. Enquête Pratiques culturales 2011. http://agreste.agriculture.gouv.fr/ IMG/pdf/dossier21 integral.pdf

Angers D., Recous S., Aita C., 1997. Fate of carbon and nitrogen in water-stable aggregates during decomposition of wheat straw. European Journal of Soil Science 48, 295-300.

Asner G.P., Seastedt T.R., Townsend A.R., 1997. The decoupling of terrestrial carbon and nitrogen cycles. Bioscience, 47, 4, 226-234.

Attard E., Le Roux X., Charrier X., Delfosse O., Guillaumaud N., Lemaire G., Recous S., 2016. Delayed and asymmetric responses of soil $\mathrm{C}$ pools and $\mathrm{N}$ fluxes to grassland/cropland conversions. Soil Biology and Biochemistry 97, 31-39.

Balesdent J., Chenu C., Balabane M., 2000. Relationship of soil organic matter dynamics to physical protection and tillage. Soil and Tillage Research 53, 215-230.

Bertrand I., Chabbert B., Kurek B., Recous S., 2006. Can the biological features and histology of wheat residues explain their decomposition in soil? Plant and Soil 281, 291-307

Billen G., Lassaletta L., Garnier J., 2014. A biogeochemical view of the global agro-food system: Nitrogen flows associated with protein production, consumption and trade. Global Food Security 3, 209-219.

Billen G., Silvestre M., Grizzetti B., Leip A., Garnier J., Voss M., Howarth R., Bouraoui F., Lepisto A., Kortelainen P., Johnes P., Curtis C., Humborg C., Smedburg E., Kaste O., Ganeshram R., Beusen A., Lancelot C., 2011. Nitrogen flows from European watersheds to coastal marine waters. In: Sutton, M. A. (ed.).The European Nitrogen Assessment. Cambridge University Press, Cambridge, pp. 271-297. ISBN 9781107006126

Booth M. S., Stark J. M., Rastetter E., 2005. Controls on nitrogen cycling in terrestrial ecosystems: A synthetic analysis of literature data. Ecological Monographs, 75, 139-157.

Burke I.C., Yonker C.M., Parton W.J., Cole C.V., Flach K., Schimel D.S., 1989. Texture, Climate, and Cultivation Effects on Soil Organic Matter Content in U.S. Grassland Soils. Soil Science Society of America Journal 53, 800-805.

Butterbach-Bahl K., Gundersen P., Ambus P., Augustin J., Beier C., Boeckx P., Dannenmann M., Sanchez Gimeno B., Ibrom A., Kiese R., et al., 2011. Nitrogen processes in terrestrial ecosystems. In: The European nitrogen assessment: sources, effects and policy perspectives. Mark A Sutton, Clare M Howard, Jan Willem Erisman, Gilles Billen, Albert Bleeker, Peringe Grennfelt, Hans van 
Grisven and Bruna Grizzetti (Eds.), 99 - 125, Cambridge University Press, Cambridge, UK, ISBN 9781107006126

Cakmak I., 2002. Plant nutrition research: Priorities to meet human needs for food in sustainable ways. Plant and Soil 247, 3-24.

Cassman K.G., Dobermann A., Walters D.T., 2002. Agroecosystems, Nitrogen-use Efficiency, and Nitrogen Management. AMBIO: A Journal of the Human Environment 31, 132- 140.

Chadwick O.A., Derry L.A., Vitousek P.M., Huebert B.J., Hedin L.O., 1999. Changing sources of nutrients during four million years of ecosystem development. Nature 397,491-497.

CITEPA, 2016. https://www.citepa.org/fr/air-et-climat/polluants/effet-de-serre/protoxyde-d-azoten2o (last consultation 29/07/2017)

Cleveland C.C., Liptzin D., 2007. C:N:P stoichiometry in soil: is there a Redfield ratio for the microbial biomass ? Biogeochemistry 85, 235-252.

Constantin J., Mary B., Laurent F., Aubrion G., Fontine A., Kerveillant P., Beaudoin N., 2010. Effects of catch crops, no till and reduced nitrogen fertilization on nitrogen leaching and balance in three long-term experiments. Agriculture, Ecosystems and Environment 135, 268-278.

Coppens F., Garnier P., De Gryze S., Merckx R., Recous S., 2006. Soil moisture, carbon and nitrogen dynamics following incorporation and surface application of labelled crop residues in soil columns. European Journal of Soil Science 57, 894-905.

Curtin D.,. McCallum F.M., Williams P.H., 2003. Phosphorus in light fraction organic matter separated from soils receiving long-term applications of superphosphate. Biology and Fertility of Soils $37,280-287$.

De Deyn G.B., Cornelissen J.H.C., Bardgett R.D., 2008. Plant functional traits and soil carbon sequestration in contrasting biomes. Ecology Letters 11, 516-531.

Dick R.P., 1992. A review: long-term effects of agricultural systems on soil biochemical and microbiological parameters. Agriculture, Ecosystems and Environment 40, 25-36.

Dwivedi, S. L., Lammerts van Bueren, E. T., Ceccarelli, S., Grando, S., Upadhyaya, H. D., Ortiz, R., 2017. Diversifying Food Systems in the Pursuit of Sustainable Food Production and Healthy Diets. Trends in Plant Science, 22, 842-856. 
Dimassi B., Cohan J.P., Labreuche J., Mary B., 2013. Changes in soil carbon and nitrogen following tillage conversion in a long-term experiment in Northern France. Agriculture, Ecosystems and Environment 169, 12-20.

Drinkwater L., Snapp S., 2007. Nutrients in agroecosystems: Rethinking the management paradigm. Advances in Agronomy 92, 163-+

Duru M., Therond O., Fares M., 2015. Designing agroecological transitions: A review. Agronomy for Sustainable Development, 35(4), 1237-1257.

Erisman J.W., Sutton M.A., Galloway J., Klimont Z., Winiwarter W., 2008. How a century of ammonia synthesis changed the world, Nature Geoscience 1, 636-639.

FAO, 2015. World fertilizer trends and outlook to 2018. ISBN 978-92-5-108692-6. http://www.fao.org/3/a-i4324e.pdf (last read 29/09/2017)

Fanin, N., Bertrand, I., 2016. Aboveground litter quality is a better predictor than belowground microbial communities when estimating carbon mineralization along a land-use gradient. Soil Biology and Biochemistry 94, 48-60.

Ferchaud F., Vitte G., Mary B., 2016. Changes in soil carbon stocks under perennial and annual bioenergy crops. Global Change Biology Bioenergy 8, 290-306.

Fontaine S., Henault C., Aamor A., Bdioui N., Bloor J.M.G., Maire V., Mary B., Revaillot S., Maron P.A., 2011. Fungi mediate long term sequestration of carbon and nitrogen in soil through their priming effect. Soil Biology and Biochemistry, 43(1), 86-96.

Freschet G. T., Aerts R., Cornelissen J. H. C., 2012. A plant economics spectrum of litter decomposability. Functional Ecology, 26: 56-65.

Galloway J.N., Aber J.D., Erisman J.W., Seitzinger S.P., Howarth R.W., Cowling E.B., Cosby B.J., 2003. The Nitrogen Cascade. BioScience 53, 341-356.

Giacomini S.J., Machet J.M., Boizard H., Recous S., 2010. Dynamics and recovery of fertilizer $15 \mathrm{~N}$ in soil and winter wheat crop under minimum versus conventional tillage. Soil and Tillage Research 108 51-58.

Guérif J., Richard G., Dürr C., Machet J.M., Recous S., Roger-Estrade J., 2001. A review of tillage effects on crop residues management, seedbed conditions and seedling establishment. Soil and Tillage 61, 13-32. 
Güsewell S., Freeman C., 2005. Nutrient limitation and enzyme activities during litter decomposition of nine wetland species in relation to litter N:P ratios. Functional Ecology 19, $582-$ 593.

Gusewell, S., Gessner M.O., 2009. "N:P ratios influence litter decomposition and colonization by fungi and bacteria in microcosms." Functional Ecology 23, 211-219.

Ha K.V., Marschner P., Bünemann E.K., 2008. Dynamics of C, N, P and microbial community composition in particulate soil organic matter during residues decomposition. Plant and Soil 303, 253-264.

Hart S.C., Nason G.E., Myrold D.D., Perry D.A., 1994. Dynamics of gross nitrogen transformations in an old-growth forest: the carbon connection. Ecology 75, 880-891.

Hertel O., Skjøth C.A., Reis S., Bleeker A., Harrison R.M., Cape J.N., Fowler D., Skiba U., Simpson D., Jickells T., Kulmala M., Gyldenkærne S., Sørensen L.L., Erisman J.W., Sutton M., 2012. Governing processes for reactive nitrogen compounds in the European atmosphere. Biogeosciences 9, 4921-4954.

Holland G.A., Coleman D.C., 1987. Litter placement effects on microbial and organic matter dynamics in agro ecosystems. Ecology 62, 425-433.

Hufnagl-Eichiner S., Wolf S.A., Drinkwater L.E., 2011. Assessing social-ecological coupling: Agriculture and hypoxia in the Gulf of Mexico. Global Environmental Change, 21(2), 530-539

Jangid K., Williams M., Franzluebbers A., Sanderlin J., Reeves J.H., Jenkins M.B., Endale D.M., Coleman D.C., Whitman W.B., 2008. Relative impacts of land-use, management intensity and fertilization upon soil microbial community structure in agricultural systems. Soil Biology and Biochemistry 40, 2843-2853.

Jarvis S., Hutchings N., Brentrup F., Olesen J.E., van de Hoek K.W., 2001. Nitrogen flows in farming systems across Europe. In The European Nitrogen Assessment, ed. Mark A. Sutton, Clare M. Howard; Jan Willem Erisman, Gilles Billen, Albert Bleeker, Peringe Grennfelt, Hans van Grinsven, Bruna Grizzetti. Cambridge University Press 2011, 211-227.

Jensen L.S., Salo T., Palmason F., Breland T.A., Henriksen T.M., Stenberg B., 2005. Influence of biochemical quality on $\mathrm{C}$ and $\mathrm{N}$ mineralisation from a broad variety of plant materials in soil. Plant and Soil 273, 307-326 
Justes E., Mary B., Nicolardot B., 1999. Comparing the effectiveness of radish cover crop, oilseed rape volunteers and oilseed rape residues incorporation for reducing nitrate leaching. Nutrient Cycling in Agroecosystems 1999, 55 207-220.

Justes E., Mary B., Nicolardot B., 2009. Quantifying and modelling C and N mineralization kinetics of catch crop residues in soil: parameterization of the residue decomposition module of STICS model for mature and non-mature residues. Plant and Soil 325, 171-185.

Kallenbach C., Grandy A.S., 2011. Controls over soil microbial biomass responses to carbon amendments in agricultural systems: a meta-analysis. Agriculture, Ecosystems and Environment 144, 241-252.

Klumpp K., Fontaine S., Attard E., Le Roux X., Gleixner G., Soussana J.-F., 2009. Grazing triggers soil carbon loss by altering plant roots and their control on soil microbial community. Journal of Ecology 97, 876-885.

Kopittke P. M., Dalal R. C., Finn D., Menzies N. W.; 2017. Global changes in soil stocks of carbon, nitrogen, phosphorus, and sulphur as influenced by long-term agricultural production. Global Change Biology 23, 2509-2519.

Kremen, C., Miles, A., 2012. Ecosystem Services in Biologically Diversified versus Conventional Farming Systems : Benefits, Externalities, and Trade-Offs. Ecological and Society, 17(4).

Lashermes G., Nicolardot B., Parnaudeau V., Thuries L., Chaussod R., Guillotin M.L., Lineres M., Mary B., Metzger L., Morvan T., Tricaud A., Villette C., Houot S., 2010. Typology of exogenous organic matters based on chemical and biochemical composition to predict potential nitrogen mineralization. Bioresource Technology, 101, 157-164

Le Noë J., Billen G., Garnier P., 2017. How the structure of agro-food systems shapes nitrogen, phosphorus and carbon fluxes: the generalized representation of agro-food system applied at the regional scale in France. Science of the Total Environment 586, 42-55.

Le Noë J., Billen G., Lassaletta L., Silvestre M., Garnier P., 2016. La place du transport de denrées agricoles dans le cycle biogéochimique de l'azote en France : un aspect de la spécialisation des territoires. Cahiers Agricultures, 25, 15004.

Lu M., Yand Y., Luo Y., Fang C., Zhou X., Chen J., Yang X., Li. B., 2011. Responses of ecosystem nitrogen cycle to nitrogen addition: a meta-analysis. New Phytologist 189, 1040-1050. 
Machet J.M., Pierre D., Recous S., Rémy J.C., 1987. Signification du coefficient réel d'utilisation et conséquences pour la fertilisation azotée des cultures. Comptes-rendus de l'Académie d'Agriculture de France 73, 3, 39-55.

Machet J.M., Dubrulle P., Damay N., Duval R., Julien J.-L., Recous S., 2017. A dynamic decisionmaking tool for calculating the optimal rates of $\mathrm{N}$ application of 40 annual crops while minimising the residual level of mineral $\mathrm{N}$ at harvest. Agronomy, 7(4), 73.

Manzoni S., Taylor P., Richter A., Porporato A., Ågren G. I., 2012. Environmental and stoichiometric controls on microbial carbon-use efficiency in soils. New Phytologist 196, 79-91.

Mary B., Cohan J.P., Dimassi B., Recous S., 2015. Effets du travail du sol sur les cycles biogéochimiques de l'azote et du carbone : de la compréhension des mécanismes aux conséquences pour la gestion des pratiques agricoles In Faut-il travailler le sol ? Acquis et Innovations pour une agriculture durable Savoir-Faire QUAE - Arvalis Institut du Végétal Versailles, France, pp 63-85. ISBN 978-2-7592-2193-6

Mbuthia L., Acosta-Martínez V., DeBruyn J., Schaeffer S., Tyler D., Odoi E., Mpheshea M., Walker F., Eash N., 2005. Long term tillage, cover crop, and fertilization effects on microbial community structure, activity: Implications for soil quality. Soil Biology and Biochemistry 89, 2434.

McLauchlan K., 2006. The Nature and longevity of agricultural impacts on soil carbon and nutrients: a review. Ecosystems 9, 1364-1382.

Ministère de la transition écologique et solidaire, France, 2015. http://www.statistiques.developpement-durable.gouv.fr/lessentiel/ar/2396/0/surplus-phosphorefrance.html (last read online 03/08/2017)

Meynard J.M., Justes E., Machet J.M., Recous S., 1997. Fertilisation azotée des cultures annuelles de plein champ. In "Maîtrise de l'azote dans les agrosystèmes", (G. Lemaire et B. Nicolardot eds), Les Colloques 83, INRA eds, Paris, 183-200.

Mooshammer M., Wanek W., Zechmeister-Boltenstern S., Richter A., 2014. Stoichiometric imbalances between terrestrial decomposer communities and their resources: mechanisms and implications of microbial adaptations to their resources. Frontiers in Microbiology 5, 22.

Murty D., Kirschbaum MUF., McMurtrie RE., McGilvray A., 2002. Does conversion of forest to agriculture land change soil carbon and nitrogen? A review of the literature. Global Change Biology 8, 105-23. 
Nemecek T., Von Richthofen J. S., Dubois G., Casta P., Charles R., Pahl H., 2008. Environmental impacts of introducing grain legumes into European crop rotations. European Journal of Agronomy 28, 380-393.

Niknahad-Gharmakher H., Piutti S., Machet J.-M., Benizri E., Recous S., 2012. MineralizationImmobilization of sulphur in a soil during decomposition of plant residues of varied chemical composition and S content. Plant and Soil 360, 391-404.

Nowak B., Nesme T., David C., Pellerin C., 2015. Nutrient recycling in organic farming is related to diversity in farm types at the local level. Agriculture, Ecosystems \& Environment 204, 17-26.

Oorts K., Laurent F., Mary B., Thiébeau P., Labreuche J., Nicolardot B., 2007. Experimental and simulated soil mineral $\mathrm{N}$ dynamics for long-term tillage systems in northern France. Soil \& Tillage Research 94, 441-456.

Østergård H., Finckh M.R., Fontaine L., Goldringer I., Hoad S.P., Kristensen K., Lammerts van Bueren E.T., Mascher F., Munk L., Wolfe M.S., 2009. Time for a shift in crop production: embracing complexity through diversity at all levels. Journal of the Science of Food and Agriculture 89, 14391445.

Pearson C.J., 2007. Regenerative, semiclosed systems: a priority for twenty-first-century agriculture. Bioscience 57, 409417.

Peňuelas J., Sardans J., Rivas-Ubach A., Janssens I.A., 2012. The human-induced imbalance between $\mathrm{C}, \mathrm{N}$ and $\mathrm{P}$ in Earth's life system. Global Change Biology 18, 3-6.

Quemada M., Baranski M., Nobel-de Lange M.N.J., Vallejoa A., Cooper J.M. 2013. Meta-analysis of strategies to control nitrate leaching in irrigated agricultural systems and their effects on crop yield. Agriculture, Ecosystems \& Environment, 174, 1-10.

Ringeval B., Nowak B., Nesme T., Delmas M., Pellerin S., 2014. Contribution of anthropogenic phosphorus to agricultural soil fertility and food production, Global Biogeochemical. Cycles 28, 743-756.

Robertson G.P., 1989. Nitrification and denitrification in humid tropical ecosystems: potential controls on nitrogen retention. In J. Proctor, editor. Mineral nutrients in tropical forest and savanna ecosystems. Blackwell Scientific, Cambridge, Massachusetts, USA, pp 55-69.

Rosenzweig S.T., Carson M.A., Baer S.G., Blair J.M., 2016. Changes in soil properties, microbial biomass, and fluxes of $\mathrm{C}$ and $\mathrm{N}$ in soil following post-agricultural grassland restoration. Applied Soil Ecology 100, 186-194. 
Sardans, J., Rivas-Ubach, A., Peñuelas J., 2012. "The C:N:P stoichiometry of organisms and ecosystems in a changing world: A review and perspectives." Perspectives in Plant Ecology Evolution and Systematics 14(1): 33-47.

Schimel J. P., Bennett J., 2004. Nitrogen mineralization challenges of a changing paradigm. Ecology 85, 591-602.

Scopel E., Triomphe B., Affholder F., Da Silva FAM., Goulet F., Corbeels E., Sabourin E., Xavier JHV, Lhamar R., Recous S., Bernoux M., Blanchart E., de Carvalho Mendes I., De Tourdonnet S., 2013. Conservation Agriculture cropping systems in temperate and tropical conditions, performances and impacts. A review. Agronomy for Sustainable Development, 33, 113-130.

Senthilkumar K., Nesme T., Mollier A., Pellerin S., 2012. Regional-scale phosphorus flows and budgets within France: The importance of agricultural production systems. Nutrient Cycling in Agroecosystems 92, 145-159.

Shcherbak I., Millar N., Robertson G.P., 2014. Global metaanalysis of the nonlinear response of soil nitrous oxide $\left(\mathrm{N}_{2} \mathrm{O}\right)$ emissions to fertilizer nitrogen. PNAS 111, 25, 9199-9204.Shepherd M., Chambers B., 2007. Managing nitrogen on the farm: the devil is in the detail. Journal of Science of Food and Agriculture 87, 558-568.

Siddique, K. H. M., Johansen, C., Turner, N. C., Jeuffroy, M. H., Hashem, A., Sakar, D., Alghamdi, S. S., 2012. Innovations in agronomy for food legumes. A review. Agronomy for Sustainable Development 32, 45-64.

Soussana J.F., Lemaire G., 2014. Coupling carbon and nitrogen cycles for environmentally sustainable intensification of grasslands and crop-livestock systems. Agriculture, Ecosystems and Environment 190, 9-17.

Stockdale E.A., Hatch D.J., Murphy D.V., Ledgard S.F., Watson C.J., 2002. Verifying the nitrification to immobilisation ratio $(\mathrm{N} / \mathrm{I})$ as a key determinant of potential nitrate loss in grassland and arable soils. Agronomie 22, $831-838$.

Sutton M.A., Oenema O., Erisman J.W., Leip A., van Grinsven H., Winiwarter W., 2011. Too much of a good thing. Nature 472, 159-161.

Swift M.J., Anderson, J.M., 1994. Biodiversity and Ecosystem Function in agricultural soils. In Biodiversity and Ecosystem function, E.D. Schulze and H.A. Mooney (Eds.), Springer-Verlag, Ecological studies 99, 15-41. 
Tietema A., Wessel W.W., 1992. Gross nitrogen transformations in the organic layer of acid forest ecosystems subjected to increased atmospheric nitrogen input. Soil Biology and Biochemistry 24, 943-950.

Tilman D., Cassman K.G., Matson, P.A., Naylor, R., Polasky S. 2002. Agricultural sustainability and intensive production practices. Nature 418, 671-677.

Trinsoutrot I., Recous S., Bentz B., Linères M., Cheneby D., Nicolardot B., 2000. Relationships between biochemical quality of crop residues and $\mathrm{C}$ and $\mathrm{N}$ mineralisation kinetics under nonlimiting $\mathrm{N}$ conditions. Soil Science Society of America Journal 64, 918-926.

Trivedi P., Delgado-Baquerizo M., Anderson I.C., Singh B.K., 2016. Response of soil properties and microbial communities to agriculture: implication for primary productivity and soil health indicators. Frontiers in Plant Science 7, 990.

Trivedi P., Rochester I.J., Trivedi C., Van Nostrand J.D., Zhou J., Karunaratne S., Anderson I.C., Sing B.K., 2015. Soil aggregate size mediates the impacts of cropping regimes on soil carbon and microbial communities. Soil Biology and Biochemistry 91, 169-181.

Van Groenigen J.W., Velthof G.L., Oenema O., Van Groenigen K.J., Van Kessel C., 2010. Towards an agronomic assessment of $\mathrm{N}_{2} \mathrm{O}$ emissions: a case study for arable crops. European Journal of Soil Science 61, 903-913.

Vance, C.P., 2001. Symbiotic Nitrogen Fixation and Phosphorus Acquisition. Plant Nutrition in a World of Declining Renewable Resources. Plant Physiology 127, 390-397.

Vandermeer J., van Noordwijk M., Anderson J., Ong C., Perfecto I., 1998. Global change and multi-species agroecosystems: concepts and issues. Agriculture, Ecosystems and Environment $67,1-22$.

Vigil M. F., Kissel D.E., 1991. Equations for Estimating the Amount of Nitrogen Mineralized from Crop Residues. Soil Science Society of America Journal 55, 757-761.

Vitousek P.M, Howarth R.W., 1991. Nitrogen limitation on land and in the sea: How can it occur? Biogeochemistry 13, 87-115.

Watson C.J., Mills C.L., 1998. Gross nitrogen transformations in grassland soils as affected by previous management intensity. Soil Biology and Biochemistry 30, 743-753.

Zak D. R., Holmes W. E., White D. C., Peacock A. D., Tilman D., 2003. Plant diversity, soil microbial communities, and ecosystem function: are there any links? Ecology 84, 2042-2050. 
(c) $(7)$ ()ㅜㅇㅛ 